\title{
Canada's Carbon-Capital Elite: A Tangled Web of Corporate Power
}

\author{
William K. Carroll
}

Abstract. This article maps the organization of corporate power in a carbon-capital elite, centred in Calgary, whose reach extends nationally and transnationally. It charts the elite's accumulation base, its internal structure as a network of interlocking directorates and its ties to the financial sector and other segments of corporate capital - national and transnational. The analysis identifies a tightly-knit, local network of mid-sized carbon-capital firms, linked into the broader power structure largely through mediating relations involving the largest carbon-capital corporations. The architecture of corporate power resembles an entrenched oligarchy; however, both policy sociology and public sociology can contribute toward checking its power through effective regulation while facilitating discussion of energy democracy as a transformative alternative.

Keywords: Corporations; Corporate elites; Carbon capitalism; Interlocking directorates; Corporate networks

Résumé. Cet article trace un portrait de l'organisation du réseau de conseils d'administration croisés qui relie entre eux les membres de l'élite économique actifs dans le secteur des combustibles fossiles au Canada. Il décrit les grandes entreprises sur lequelles se fonde le pouvoir économique de cette élite, la structure interne du réseau qui unit les entreprises du secteur entre elles, ainsi que les liens qu'elles entretiennent avec le secteur financier et les autres secteurs économiques au Canada et à travers le monde. L'analyse identifie un noyau dense d'entreprises de combustibles fossiles de taille moyenne basé à Calgary, qui participent à un réseau plus vaste par le truchement des plus grandes entreprises du secteur. Cette architecture suggère l'existence d'une oligarchie organisée autour du secteur des énergies fossiles canadien. L'analyse, fondée sur la sociologie politique et la sociologie publique, suggère une réglementation stricte du secteur, ce qui contribuerait à mitiger le pouvoir de cette oligarchie. Ce point de vue contribue également à insérer au coeur du débat le concept de démocratie énergétique en tant que projet de société alternatif.

Mots cles: Sociétés; Élites corporatives; Capitalisme du carbone; Directives d'interconnexion; Réseaux d'entreprise 


\section{INTRODUCTION}

This article maps the elite network in and around Canada's carboncapital sector, the epicentre for what former Prime Minister Stephen Harper heralded as Canada's emergence as an "energy superpower" (quoted in Stendie and Adkin 2016:417). In examining this sector we confront a troubling reality: as climate crisis has become widely recognized as the most urgent problem facing humankind, the Canadian economy has become centred upon carbon extraction as a core industry. In mapping the sector's social organization and its linkages to other components of the Canadian and global economy this article addresses possible obstacles, posed by corporate control over carbon resources, to a socially just, low-carbon future.

There can be little doubt that Canada's economy has come to be focused significantly around carbon extraction. Since the 1960s, high sectoral profit rates and a regime of low royalties (particularly in Alberta) have drawn capital to a burgeoning oil and gas sector. In the first decade of the $21^{\text {st }}$ century the value of Canada's energy exports more than quadrupled (Carter 2014). At the end of 2011, the Toronto Stock Exchange listed 405 oil and gas companies with a total market capitalization exceeding \$379 billion (Lee and Ellis 2013:6). As oil and gas revenues came to dominate the economy, Canada's dollar began to trade as a petro-currency, raising concerns about a Canadian-style Dutch Disease: a soaring dollar spelt trouble for exporters of manufactured goods, thereby weakening investment in manufacturing. By 2010 Alberta had eclipsed Ontario as the province with the largest share of the nation's capital stock (McCormack and Workman 2015:33), torqueing the national economy toward fossil fuels (FFs) as the driver of industrial accumulation. Worldwide, the sector has been described by former oil consultant Jeremy Leggett as "the most powerful interest group on the planet" (2005:12). What Urry (2013:76) terms carbon capital "has been enormously effective in wielding power, especially in the USA but also within Britain, the Russian Federation, parts of Africa and Latin America, and most MiddleEastern countries."

Concerns about the power of carbon capital have been encapsulated in recent political-ecological literature that views Alberta as a first world petro-state. In such states, heavy reliance on oil rents and the identification (promoted by state and industry) of the interests of carbon capitalists with the general interests of the citizenry leads to a "petrofied climate policy" (Adkin 2016:22) which obstructs progress on carbon emissions reduction. The capital-intensive investment in carbon extraction, further intensified with resort to extreme energy, means that employment in 
these operations is slight - the lowest of any sector in Canada - relative to output and emissions. Estimates for global employment in the sector are only about 10 million worldwide. In Canada, employment is about 120,000 including fossil fuel extraction, coal and petroleum manufacturing products and support activities, or well less than $1 \%$ of total employment, with tar sands employment assessed at around 20,000 jobs (Albo and Yap 2016). Carbon-capital operations generate revenue for corporations, royalties for petro-states and escalating emissions, but offer few jobs to working people.

According to some scholars, the entrenched power of carbon capital is increasingly at odds with a growing global consciousness about the deepening climate crisis, informing tentative steps toward corralling global carbon emissions within an evidence-based carbon budget, and ultimately questioning "fossil capital" as the centrepiece of economic life (see Atlever 2006; Malm 2016). In Canada, where tar sands development has claimed a major share of capital investment, "Albertans and Canadians alike risk being stranded by the worldwide evolution away from petroleum" (Clarke, Gibson, Haley and Stanford 2013:71) which accelerated after the collapse of oil prices in 2014-15.

In the same period that the carbon-extractive sector came to dominate Canada's industrial economy, the closely tied issues of concentrated corporate power and growing economic inequality gained salience. The share of total national net corporate profits claimed by the 60 large corporations comprising the Toronto Stock Exchange TSX60 - 35\% in 1961 - grew by 2010 to an astonishing 60 percent (Brennan 2012:20). Since the early 1990s, when the market-driven, neoliberal policy framework became consolidated in Canada, concentration of corporate capital has closely tracked concentration of income in the hands of an elite few, producing an "unprecedented concentration of both income and corporate power" (Brennan 2012:40). The neoliberal "freeing" of markets through deregulating capital, privatizing public assets and eroding the tax base for public initiatives has reinforced capitalism's tendencies toward oligarchy. Worldwide, a 2011 study estimated that a "super-entity" of 147 tightly knit companies (whose shares were substantially held by other super-entity members) controls 40 per cent of the total wealth in the global network of 43,060 TNCs. Giant financial institutions, many of them administering pension funds and other institutional investments, comprised three-quarters of the super-entity (Vitali, Glattfelder and Battiston 2011:6).

These tendencies have long been evident, not only in economic concentration but in structures of ownership and control that amplify economic inequities, enabling major investors, including financial institu- 
tions, to control "other people's money" (Brandeis 1914). Democratic organizations operate on the principle of one member, one vote, but in corporations each share provides a vote to its owner. Since share ownership is concentrated among a few major shareholders (including wealthy families, other corporations and institutional investors), these interests elect the board of directors which appoints senior management. In this way, the vast majority of shareholders are disenfranchised, as corporate power is concentrated not only within a relative few companies but among the major shareholders, directors and executives of those companies.

Moreover, and in contrast to the notion that Canadian capitalism comprises a free-market system, it is not unusual for corporate directorates to be interlocked, i.e., for large corporations to share the same directors (and sometimes executives). Elite extra-market relations among the largest companies create the basis for a "corporate community" (Domhoff 2006). The well-connected networkers at the centre comprise an "inner circle," further concentrating corporate power within what Useem (1984) has termed the dominant stratum of the capitalist class. The elite social relations that underpin this community diverge sharply from the fictional narrative of firms isolated from and in competition with each other. Directorate interlocks provide a structural basis for communication, coordination, and social cohesion, enabling the corporate community to define and pursue its common interests in maintaining the status quo of concentrated corporate power (Brownlee 2005; Sapinski and Carroll 2017).

In Canada, a research program mapping the corporate elite was inaugurated by John Porter in the 1950 s $(1956 ; 1965)$ and advanced by his student Wallace Clement (1975). More recent work has used social network analysis (SNA) to situate the Canadian corporate power structure within a transnational context (Carroll 2004; Carroll and Klassen 2010; Klassen and Carroll 2014; Carroll 2016). These studies have opened a window on the social organization of Canadian capitalism in an era of globalizing capitalism, but they have not considered how carbon capital is positioned within the power structure; nor has this issue been addressed in the international literature.

\section{The Carbon-Capital Elite}

Corporate community, corporate elite, inner circle and dominant stratum are terms that flag the enormous concentration of power in a relatively small group of business leaders - the result of a combination of eco- 
nomic concentration, concentration of share ownership, and elite social networking. If carbon capital has become a leading industrial sector, it is worthwhile to map the organization of corporate power within the carbon-capital elite that directs and manages those corporations. In turn, the carbon-capital sector is integrated with the broader national and transnational economy. Besides supply chains that link carbon-extraction into other economic sectors there is a strong co-dependency between fossil-fuel corporations and the financial sector. In an era of extreme oil (Pineault 2016) extractive megaprojects require massive financing; thus, corporate power over carbon extraction and processing is closely tied to corporate power in financing those activities (Albo and Yap 2016). These initial reflections lead to three research questions:

1. What is the carbon-capital elite's accumulation base (Carroll 1986, Carroll and Klassen 2010): what combination of carbonextractive companies provides a basis for the streams of profit upon which the elite's power ultimately depends?

2. How is the carbon-capital elite internally structured as a network of interlocking directorates, which operates simultaneously at two levels: that of the corporation and that of the individual (Carroll 1984)?

3. How is the elite linked to the financial sector and other segments of corporate capital - national and transnational?

Answers to these will illuminate our understanding of Canada's carboncapital elite as a distinct grouping or fraction, embedded within wider networks of corporate power.

\section{Method}

Since the pioneering work of Mills (1956) and Porter (1956) methods for mapping elite relations among directors and executives have advanced our knowledge of corporate power's social organization (Fennema and Heemskerk 2017). Although many studies begin by identifying the largest companies within a geographical space, our interest in the carboncapital elite suggested a different sampling method. We began with the list of 114 carbon-extractive corporations with assets of at least $\$ 50$ million, developed by Lee and Ellis (2013). To that we added 124 corporations involved in carbon extraction, transport and processing, identified through searches of online databases, resulting in a "core sample" of 238 FF companies based in Canada, each with assets at yearend 2014 of at least $\$ 50$ million. The selection process then snowballed to several 
thousand companies, as we selected first-order neighbours (i.e. other firms directly linked to the core sample by interlocking directorates) and then second-order neighbours (i.e. linked indirectly to core-sample firms, via interlocks with first-order neighbours), using the online database ORBIS, which covers several million companies worldwide. ${ }^{1} \mathrm{We}$ then gathered data on the directors and executives of all core and neighbour firms (direct and indirect) as well as company-level variables such as size, industry and location of head office. Snowballing enables us to analyze carbon-sector firms as embedded nodes in wider networks of interlocking: to locate the carbon-capital elite within the neighbourhoods of the Canadian and foreign-based corporations that form a global power structure.

The snowballing procedure identified an initial list of 15,569 corporations, 1547 of which were direct neighbours to core-sample firms. Since our research interest lay in mapping Canada's carbon-capital sector within the network of the largest corporations, we introduced size criteria that excluded the smaller neighbours from the analysis. Our sample is thus comprised of several Top Strata (cf. Carroll and Klassen 2010), which include the largest Canada-based neighbours (direct and indirect) to FF firms and the largest foreign-based neighbours (direct and indirect). The size criteria were geared to generating Canadian and foreign strata that would be analytically manageable. We selected Canadian-based direct and indirect neighbours with revenue of $\$ 100$ US million or more $(n=155$ and 244 , respectively). This revenue floor is equal to that of the $130^{\text {th }}$ ranked firm in our core sample; thus, the strata of Canada-based neighbours include very large firms as well as firms similar in size to mid-sized FF firms. We selected foreign-based direct neighbours with revenue of $\$ 1$ billion or more $(n=258)$ and foreign-based indirect neighbours with revenue of $\$ 27$ billion or more $(n=363)$. This stratification procedure yielded a sample of 1258 Top Strata corporations, including 637 Canada-based companies and 621 foreign-based companies (see Figure 1). With it, we can map the Canada-based carbon sector as it is embedded within the national and global formation of the largest corporations, but we need to remain aware of the size differences between strata that are built into this methodology.

1. This network-snowballing methodology is not without precedent in Canada. Piedalue (1976) employed the same approach in mapping the bank-centred network of interlocking directorates between 1900 and 1930 . 
Figure 1: Defining Top Strata within the larger sample

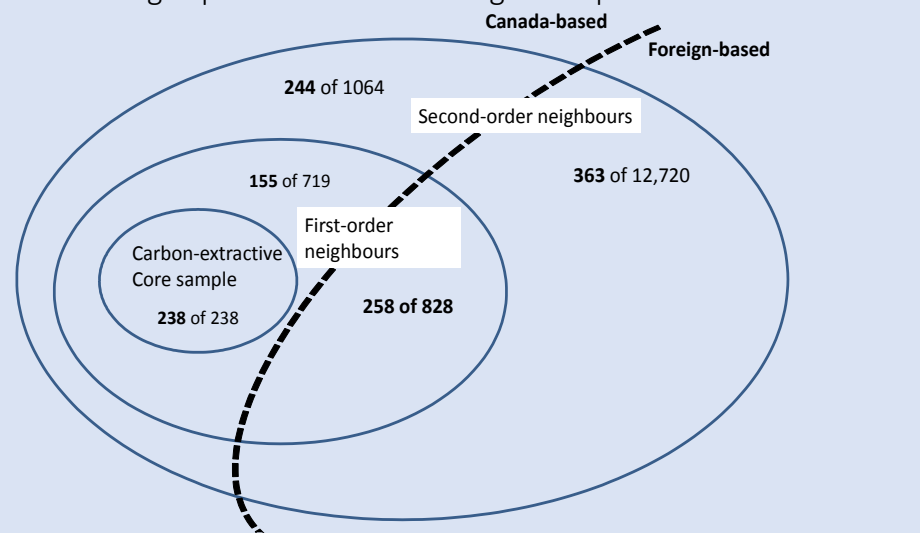

In Table 1 we see how the elite network is carried by a relatively small segment of corporate directors and executives. The 22,917 directors and executives of the 1258 corporations generate over 9000 interlocks; however, most individuals $(79.1 \%)$ are affiliated with single corporations. Most corporate networkers are affiliated with two firms, creating a single interlock. Yet most of the interlocks -3 out of 5 - are carried by networkers who have three or more corporate affiliations. The 481 "big linkers" (each with four or more affiliations), a mere $1.7 \%$ of all directors and executives, account for nearly two in five interlocks. The network is largely the domain of an elite within the elite, an "inner circle" of wellconnected individuals (Useem 1984).

Table 1: Affiliations in the database and the interlocks they generate

\begin{tabular}{|l|l|l|l|l|}
\hline $\begin{array}{l}\text { N of } \\
\text { affiliations }\end{array}$ & $\begin{array}{l}\text { N of } \\
\text { directors/executives }\end{array}$ & $\begin{array}{l}\text { \% of } \\
\text { directors/executives }\end{array}$ & $\begin{array}{l}\text { Interlocks } \\
\text { generated }\end{array}$ & $\begin{array}{l}\text { Percent } \\
\text { of all } \\
\text { interlocks }\end{array}$ \\
\hline 1 & 18122 & 79.1 & 0 & 0.0 \\
\hline 2 & 3731 & 16.3 & 3731 & 40.2 \\
\hline 3 & 683 & 3.0 & 2049 & 22.1 \\
\hline 4 & 243 & 1.1 & 1458 & 15.7 \\
\hline 5 & 64 & 0.3 & 640 & 6.9 \\
\hline 6 & 53 & 0.2 & 795 & 8.6 \\
\hline $7+$ & 21 & 0.1 & 603 & 6.5 \\
\hline Total & 22917 & 100.0 & 100.0 \\
\hline
\end{tabular}




\section{The Carbon-Capital Elite's Accumulation Base}

How can we characterize the accumulation base that the 238 Canadabased FF companies provides for the carbon-capital elite? As already noted, a fundamental structuring condition in corporate capitalism is extreme disparities in the distribution of capital across firms. Generally, economic sectors, national economies and the global economy are dominated by a few large companies, concentrating corporate power in the hands of their owners, directors and executives. Within the carbonextractive sector, this is the basis for distinguishing between the handful of "majors" and the many mid-sized firms, as shown in the distribution of total revenue at yearend 2014 (Figure 2). A handful of very large corporations claim most of the revenue generated in the sector. The top 15 revenue-earners listed in Table 2, hereafter the "majors", comprise only $6.3 \%$ of core-sample firms but claim $63.5 \%$ of total revenue. They include six of the eight integrated FF companies based in Canada and five of 18 pipeline companies. In these capital-intensive sub-sectors, value flows are extremely concentrated: among integrated FF companies the majors account for $97.5 \%$ of revenue; among pipeline companies they account for $70.6 \%$. In other sub-sectors - non-integrated oil and gas extraction $(30 \%)$, services to extraction $(15.2 \%)$ and coal/bitumen mining $(47.4 \%)$ - majors represent less than half of total revenue. ${ }^{2}$

Figure 2: Distribution of total 2014 revenue within core sample

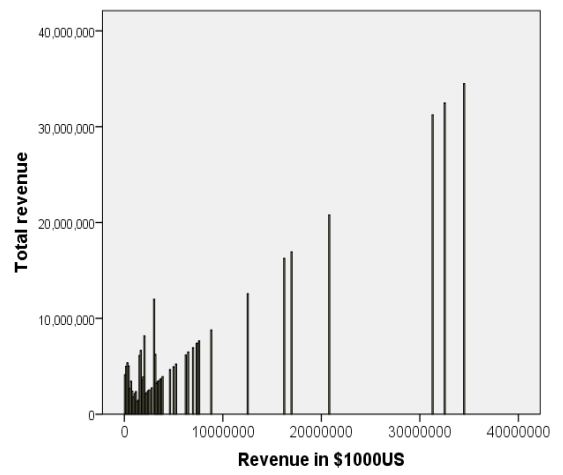

2. Services to extraction mainly involve services to production (drilling, transport). Coal/bitumen mainly includes coal mining, but also five firms that mine bitumen exclusively. Three coal firms also mine bitumen. Five of the seven integrated producers extract bitumen, along with nine of the 130 nonintegrated oil and gas producers. 
Table 2: 15 majors in the core sample of 238 FF corporations

\begin{tabular}{|l|l|l|}
\hline Corporation name & $\begin{array}{l}\text { Revenue } \\
\text { (\$US) }\end{array}$ & Main activity \\
\hline SUNCOR ENERGY INC & 34487065 & integrated oil and gas \\
\hline ENBRIDGE INC & 32474298 & pipelines \\
\hline IMPERIAL OIL LIMITED & 31236313 & integrated oil and gas \\
\hline HUSKY ENERGY INC & 20785069 & integrated oil and gas \\
\hline CENOVUS ENERGY INC & 16945887 & integrated oil and gas \\
\hline $\begin{array}{l}\text { CANADIAN NATURAL } \\
\text { RESOURCES LTD }\end{array}$ & 16273815 & oil and gas extraction \\
\hline SHELL CANADA LTD & 12575966 & integrated oil and gas \\
\hline TRANSCANADA CORP & 8786980 & pipelines \\
\hline ENCANA CORP & 7644712 & pipelines \\
\hline TECK RESOURCES LTD & 7418679 & coal \\
\hline GIBSON ENERGY INC. & 7396704 & pipelines \\
\hline CORPORATION & 6938304 & oil and gas extraction \\
\hline TALISMAN ENERGY INC & 6185000 & integrated oil and gas \\
\hline PEMBINA PIPELINE & 5235953 & pipelines \\
\hline & 6494375 & services to extraction \\
\hline
\end{tabular}

The carbon-capital elite is shaped by a geography of accumulation. Carbon capital clusters spatially, around centres of strategic command. Fourfifths of companies are headquartered in Calgary (Figure 3), representing $87.3 \%$ of total sectoral revenue. Only Toronto (13 firms accounting for $4 \%$ of sectoral revenue) and Vancouver (15 firms accounting for 3.7\%) host any substantial number of companies (five corporations based in Edmonton claim only $0.2 \%$ of revenue). 
Figure 3: Core sample of 238 FF corporations: city of head office

n of firms

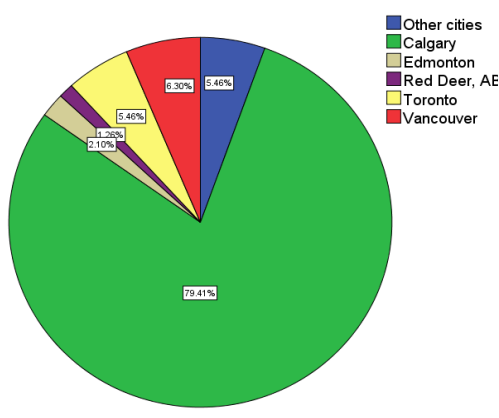

revenue of firms

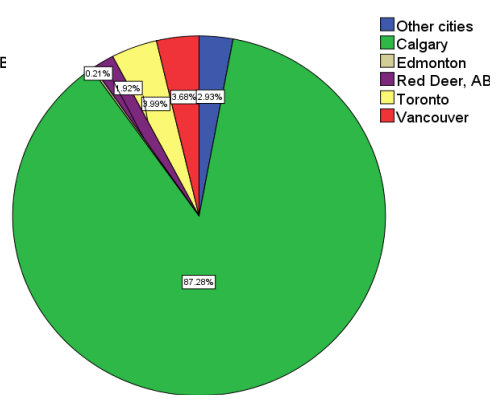

Complementing head office location is location of investments. We developed a typology that views this aspect of corporate geography from the standpoint of Western Canada, noting whether firms have substantial investments in Western Canada, in the rest of Canada (ROC), in the US, or beyond the US. Two-fifths of companies are active solely in Western Canada (including four western provinces and the northern territories, see Figure 4). Another 37.4\% are active in Western Canada but also elsewhere. Many of these are active in the US (15.5\%) and beyond (16.8\%). Very few firms not invested in Western Canada are active elsewhere in Canada, and seven of these 11 are also invested in the US (2 firms) and beyond (5 firms).

Figure 4: Core sample: geographical reach of investments

$\mathrm{n}$ of firms

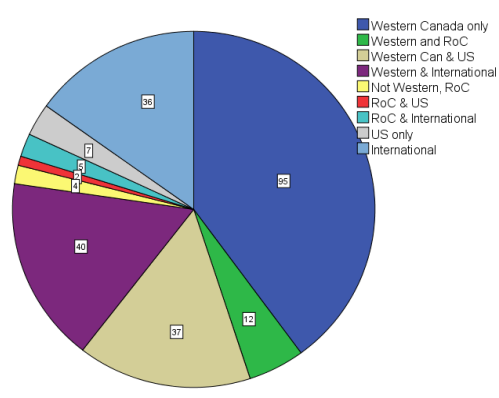

revenue of firms

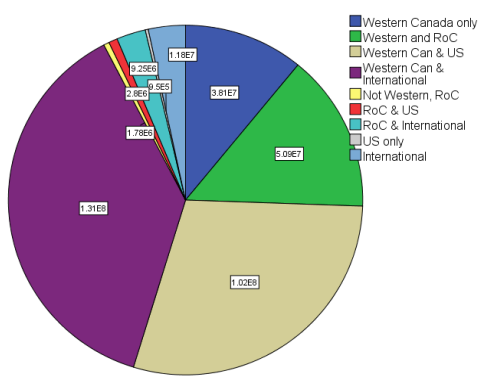


Clearly, many Canadian carbon-capital corporations centre their activities in western provinces, but some companies' investments span the globe. A sizeable stratum conducts activities entirely outside Canada, in the US (7) or more internationally (36). ${ }^{3}$ Yet in terms of the capital (revenue) they represent, firms active in Western Canada, especially those with continental $(29.3 \%)$ or international (38.9\%) investments, dominate. Indeed, firms invested in Western Canada make up $76.9 \%$ of the entire fossil-fuel sector, but account for $92.5 \%$ of revenue. The 54 firms not active in Western Canada account for only $7.5 \%$ of total revenue. Among the majors the Western Canada base is especially evident. None restricts its activities to that region but all are squarely based there. ${ }^{4}$ Clearly, the centre-of gravity of investments is the western provinces. This complements and reinforces the dominance of Calgary as the command centre for most corporate head offices.

Since publication of Kari Levitt's Silent Surrender, the significance and extent of foreign control of corporate Canada have been debated. Foreign control of corporations concentrates corporate power transnationally, in the hands of owners located elsewhere. In Levitt's (1970:116) Shumpeterian view this would lead to a "harvest of lengthening dependence", as branch-plant managers replaced innovative entrepreneurs within the business elite.

Although at the time Levitt wrote, US-based TNCs seemed poised to conquer the world, ensuing decades witnessed a decline of American hegemony and a more multilateral pattern of international investment leading to a cross-penetration of capital among the advanced capitalist countries (Klassen and Carroll 2014:164; Kellogg 2015). It is therefore not surprising that core-sample firms are predominantly controlled by Canadian capitalists, accounting for $71 \%$ of firms and $67 \%$ of total revenue. US-based corporate interests control $12 \%$ of firms and of revenue,

3. The locations of these Canadian-based foreign direct investments include: Africa (Tunisia, Morocco, Libya, Nigeria, Madagascar, Ethiopia, Kenya, Somalia, South Africa), Latin America (Mexico, the Caribbean (including Cuba), Guatemala, Brazil, Argentina, Peru, Colombia, Ecuador, Guyana, Belize, Venezuela, Chile, Uruguay), Asia (Kazakhstan, Jordan, Syria, United Arab Emirates, Iraq, Oman, Bahrain, Dubai, Yemen, Saudi Arabia, Indonesia, Brunei, Malaysia, Thailand, Indonesia, Singapore, Bangladesh, Pakistan, India, China, Mongolia, Papua New Guinea), Europe (UK offshore, Greenland offshore, Iceland, Norway offshore, Ireland, Germany, Denmark, Sweden, the Netherlands, France, Spain, Italy, Cyprus, Poland, Albania, Romania, Hungary, Russia, Georgia, Ukraine, Turkey) and Australia/New Zealand.

4. Two (Imperial Oil and Shell Canada) have major refining operations in central Canada but not beyond, six are active in the US and seven are invested more internationally (four of which are also active in the US). 
followed by China-based owners (including Hong Kong), accounting for $4 \%$ of firms but $11 \%$ of revenue (see Figure 5). Foreign control is concentrated within a few of the largest firms. Six of 15 majors are foreign controlled: Imperial Oil (US), Gibson Energy (UK), Talisman Energy (Spain), Shell Canada (Netherlands), Husky Energy (China-Hong Kong) and Nexen Inc (China). These represent $75 \%$ of the total sectoral revenue under foreign control. ${ }^{5}$

Figure 5: Core sample: country of control

n of firms

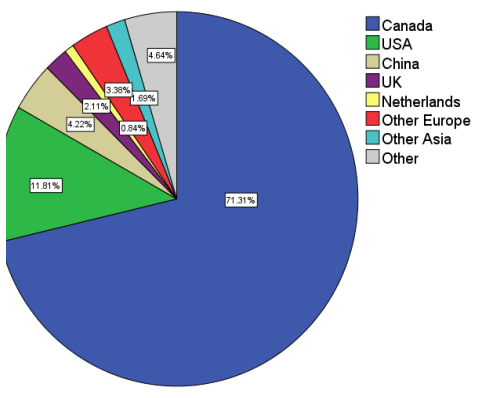

revenue of firms

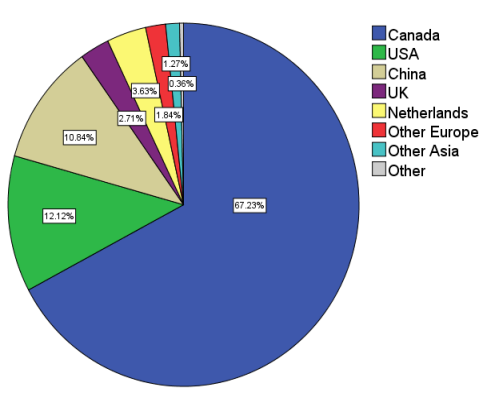

To summarize, the accumulation base for Canada's carbon-capital elite is bifurcated between a few majors and many mid-sized corporations. The elite's centre-of gravity is western Canada (specifically, Calgary) but the capital it manages is extensively transnationalized. Most of the sector's revenue flows through companies whose investments reach beyond Canada's borders. Although the carbon-capital elite directs and manages corporations controlled mainly in Canada, some firms (including several of the majors) are controlled by interests in the US, China and Europe. Although centred in western Canada and predominantly controlled by Canadian interests, Canada's carbon-capital elite directs outward-bound international business activities while being penetrated by foreign inter-

5. Data for the analysis of foreign control (as of late 2015) are from FP.Infomart and ORBIS. We classified each FF corporation as to the country in which the owning interest is based. Revenue was not available for nine private corporations, including three controlled in Canada (Sprott Resource Corp, Canada Energy Partners Inc. and Altex Energy Ltd), four controlled in the US (Murphy Oil Co Ltd, Chevron Canada Resources, Exxonmobil Canada and Prairie Mines \& Royalty Ltd), one controlled in France (Total Fina Elf E \& P Canada) and one controlled in Japan (Grande Cache Coal Corporation). Our estimates of revenue under foreign control are probably slightly conservative. 
ests. It participates in the cross-penetration of investment that is integral to capitalist globalization, and to formation of a transnational capitalist class (Carroll 2010).

\section{Social Organization of the Carbon-Capital Elite}

Turning now to our second research question, a basic issue is whether elite interlocking within the carbon-capital sector provides a basis for a corporate community: whether the network is integrated, or fragmented into many disconnected pieces. In this section we present a network analysis of the interlocks created by the multiple affiliations of directors and executives of carbon-capital firms.

Results of snowball sampling (see Figure 1) already showed that the carbon-capital elite is embedded in a national and transnational network. Its members interlock directly or at one remove with more than 15,000 corporations, nearly 2,000 of which are based in Canada. ${ }^{6}$ Yet the entire network could still be disjointed if companies formed cliques, interlocking with each other to the exclusion of outsiders. Here, the question is not simply whether firms interlock with other corporations, but whether their neighbours interlock with each other, i.e., whether the neighbourhoods of core-sample firms overlap. Focusing on the 1,258 Top Strata corporations we find that $92.4 \%$ form a connected component in which all members are directly or indirectly linked. This means that the neighbourhoods of carbon-capital firms overlap, constituting a single network. Its density is $0.007: 0.7 \%$ of all pairs of companies are interlocked. Overall, the network is quite sparse (as large networks typically are); yet this does not preclude the possibility of relatively dense subnetworks, as we shall see.

Any network is composed of points (or nodes) and lines (or edges). The nodes are characteristically organized along a dimension of centrality: some are positioned at or near the network's core; others are on its margins. The most basic index of centrality is degree, which in this case is simply the number companies with which a given corporation is interlocked. Within our TopStrata sample, the mean degree is 7.74. As with the distribution of capital, the distribution of interlocking is skewed (though not as severely): the most central $10 \%$ of corporations (each with a degree of at least 17) accounts for $31.0 \%$ of all interlocking.

6. Note that our methodology constructs a view of the corporate power structure from a specific starting point in Canada's FF sector. This purposefully highlights the prominence of that sector. 
In addition to simple degree, a measure of centrality that takes into account how central one's neighbours in the network are is 2-step degree: the total number of firms to which a given company is tied either directly or at one remove. Among the Top Strata corporations, the mean 2-step degree is 32.39. Degree and two-step degree can illuminate whether and how Canada's carbon-capital companies form a distinct corporate community. Considering only the interlocks that link the 238 carbon-capital firms to each other, we find that 193 of them participate in at least one interlock within the sector, the mean within-sector degree being 4.01. In addition, companies are linked at one remove to a mean of 7.34 other carbon-capital firms. All but six of the 193 firms form a connected component.

\section{Concentration of capital and network structure}

We saw earlier that carbon capital is highly concentrated, with the 15 majors claiming nearly two-thirds of revenue. This bifurcation also structures the elite network. As a metric, degree can be decomposed into internal and external components. Internal degree refers to the number of firms in the same sector with which a firm interlocks; external degree refers to the number of firms in other sectors with which the same firm interlocks. When we distinguish between "introverted" networking within Canada's FF sector (internal degree) and "extraverted" networking beyond it (external degree), what stands out is the difference between majors and others (Table 3). On average, majors interlock with 3 other carbon-capital firms, but with 11 neighbours: their networking reaches extensively beyond the carbon-capital sector, linking them at one remove to a mean of 85 companies beyond the core sample. Mid-sized core-sample companies interlock mainly with other FF firms; and their direct interlocks do not generate very many indirect ties beyond the Canadian carbon-capital sector. ${ }^{7}$ The E-I index, a measure of relative extraversion which has a theoretical maximum of 1 (complete extraversion) and minimum of -1 (complete introversion), summarizes the difference nicely. ${ }^{8}$ Majors are extraverted (mean E-I $=0.522$ ); other carbon-sector firms are introverted $(\mathrm{E}-\mathrm{I}=-0.304){ }^{9}$ The carbon-capital network appears as a two-tiered formation, divided between majors and mid-sized firms.

7. The simple contrast between 15 majors and the rest accounts for $14.7 \%$ of the variance in overall degree and $21.3 \%$ of the variance in overall 2-step degree.

8. For present purposes the E-I index subtracts the proportion of each firm's total degree that is internal to the core sample from the proportion that is external. See Krackenhardt and Stern (1988)

9. Among 238 core-sample members, the proportion of variance in E-I attributable to the distinction between majors and other firms (Eta2) is 0.081 . 
The latter form the backbone of a cohesive local elite; the former play a mediating role between mid-sized, local firms and extra-local corporate communities.

Table 3: Comparing degree of interlocking: majors and mid-sized firms

\begin{tabular}{|c|c|c|c|c|}
\hline $\begin{array}{l}\text { Size of } \\
\text { corporation }\end{array}$ & $\begin{array}{l}\text { degree in core } \\
\text { sample }\end{array}$ & $\begin{array}{l}\text { 2-step degree in } \\
\text { core sample }\end{array}$ & $\begin{array}{l}\text { degree in rest o } \\
\text { network }\end{array}$ & $\begin{array}{l}\text { 2-step } \\
\text { f degree in rest of } \\
\text { network }\end{array}$ \\
\hline Mid-sized & & & & \\
\hline & 4.07 & 7.52 & 1.80 & 8.45 \\
\hline \multirow[t]{2}{*}{ Majors } & & & & \\
\hline & 3.13 & 4.71 & 11.27 & 84.69 \\
\hline \multirow[t]{2}{*}{ Total } & & & & \\
\hline & 4.01 & 7.34 & 2.40 & 13.26 \\
\hline
\end{tabular}

Within the 15 majors, however, there is a further division: four show no ties to the other Canadian FF firms, and three of those have long been under foreign control (Husky Energy, Imperial Oil, Shell Canada; the fourth being coal giant Teck Resources, whose investments extend to non-carbon mining and smelting). On the other hand, majors invested in oil and gas and with deep roots in Canada's capitalist class do participate in the carbon-capital subnetwork, though not to the exclusion of their broader networking. This pattern is evident for Canadian Natural Resources Limited (CNRL; internal degree $=8$, external degree $=10)$, Encana $(6,15)$, Talisman Energy (5, 19), TransCanada Corporation $(5,20)$, Enbridge $(4,11)$, Nexen (4, 12) and Suncor $(4,14)$, suggesting that these firms (including two that recently fell under foreign control - Talisman and Nexen) play 
a mediating role in networking both within the local, Calgary-based community and beyond it.

\section{The core of the carbon-capital corporate community}

Looking more closely within the subnetwork of core-sample firms, differences in internal degree between majors and smaller firms point to broader variation in centrality. A quarter of carbon-capital firms do not participate in any interlocks within the subnetwork; $21.0 \%$ interlock with one carbon-capital firm and another quarter interlock with two such firms. On the other hand, $17.6 \%$ interlock with four or more other carbon-capital firms. This suggests that the carbon-capital community is organized around a dense core.

To explore this hypothesis, we dissected the connected component of 193 carbon-capital firms into successive kcores. A kcore is a connected subnetwork whose members are directly linked to at least $k$ other members (Seidman 1983). As $k$ increases, the criterion for membership is ratcheted up, leaving a smaller subnetwork of densely-connected members. The Canadian carbon-capital network does indeed contain a dense centre. Thirteen firms form a 12core - a completely connected network. Fifty-one firms form a 4core, whose density is .4047 ; i.e., $40 \%$ of its members directly interlock with each other. The 4 core includes only $21.4 \%$ of carbon-capital firms, but interlocks among its members account for $54.1 \%$ of all core-sample interlocking.

We can see in Table 4 that the 4core is made up mostly of non-integrated oil and gas producers with access to land (and thus resource rents), based in Calgary, invested in Western Canada primarily (with some capital in the rest of Canada or US), and controlled by Canadian capitalists. On the other hand, integrated producers and coal companies, and companies that provide services to extraction but do not control land, are largely absent from the network's core. On average, firms in the 4core are smaller than other carbon-sector firms, reflecting the fact that only one of the 15 majors is located within the 4core. 
Table 4: Composition of the 4core

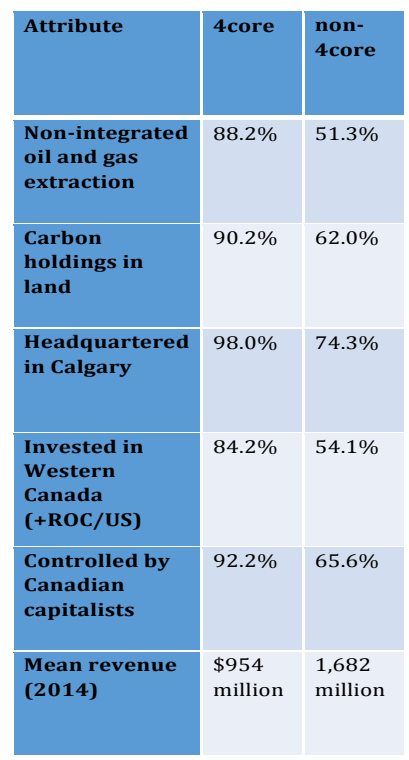

\section{Unpacking the carbon-capital elite}

A key property of corporate-interlock networks is their duality (Carroll 1984): they are composed of both corporations and the persons who actually "carry" the interlocks via their multiple corporate affiliations. Properly speaking, the carbon-capital elite refers not to corporations but to the key directors and executives in charge of them. It might be said to include both the networkers, the directors and executives of carbonextractive corporations whose multiple affiliations create the corporateinterlock network, plus presidents/CEOS and board chairs of carbonextractive firms who are not networkers but who occupy top positions of leadership and power.

Here we focus on the networkers (including 105 presidents/CEOS and 79 board chairs of core-sample firms). A total of 834 individuals create all the interlocks within Canada's carbon-extractive sector and between it and the rest of the national and international network in which it is embedded (see Table 5). Nearly a third of them hold one position in a carbon-capital firm and one position in a neighbour of some sort; another quarter hold one carbon-capital affiliation but multiple affiliations with other corporations. These 458 individuals, comprising $54.9 \%$ of all networkers, link Canada's carbon-extractive sector into the wider corporate 
elite, without themselves networking across carbon-capital firms. On the other hand, more than a quarter of all networkers $(27.6 \%)$ are network specialists entirely within Canada's carbon-extractive sector: their corporate affiliations do not extend to other industries. Another $16.5 \%$ are networkers within Canada's carbon-extractive sector and have at least one corporate affiliation beyond it. Within that category, 63 individuals (7.6\% of networkers) hold multiple affiliations with both Canadian carbon-capital companies and neighbouring companies.

\section{Table 5: Corporate networkers in the carbon-capital elite}

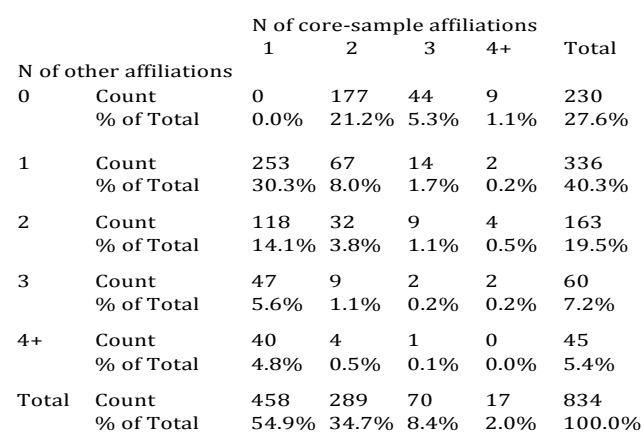

Taking the 834 networkers as an operationalization of the carbon-capital elite, we find a sharp underrepresentation of women ( $87.8 \%$ are men) and a mean age at year end 2015 of 59, with women slightly younger than men (means of 57 vs 59). An important class distinction within corporate elites is between functioning capitalists occupy higher executive positions and advisors or "organic intellectuals" who serve as outside directors of multiple firms (Niosi 1978; Carroll 2004). If the corporate network were carried mostly by advisors it might amount to little more than "window dressing" (Helland and Sykuta 2004) - a side-effect of firms retaining the same advisors. Alternatively, a network of interlocking directorates carried mainly by those in positions of authority comprises a structure of corporate power. We assigned each networker to a class category by determining his or her principal affiliation, as indicated by business databases at our disposal (primarily FP.Infomart, secondarily Bloomberg and ORBIS). Overall, advisors (including 15 legal advisors, six consultants, one academic, one state official and three other advisors) comprise $3.1 \%$ of the elite. Retired capitalists ("eminence grise") serving as outside directors - also advisors but recruited from within the class of business owners and executives - make up another 10.2\%. But 
most elite networkers are active capitalists of one sort or another. The most common position held is that of non-presidential executive (vice president, $\mathrm{CFO} /$ treasurer, secretary) in a firm within our sample $(44.5 \%$ of networkers), followed by executive and/or owner of a firm outside our sample (20.7\%). Other networkers hold top positions in sample corporations, as presidents/CEOs (6.1\%), presidents/CEOs and Chairs $(5.5 \%)$, Chairs $(5.2 \%)$ or leading shareholders $(4.6 \%, 12$ of whom were also presidents). As Table 6 indicates, women are underrepresented at the top echelons of corporate power, and over-represented among nonpresidential executives and retired capitalists. This pattern continues a patriarchal tradition, documented by John Porter (1965) in the 1950s, and only slowly eroded in subsequent years (Carroll 2004).

\section{Table 6: Class and gender in the carbon capital elite}

\begin{tabular}{|c|c|c|c|}
\hline \multirow[t]{2}{*}{ Class position } & \multicolumn{2}{|c|}{ Gender } & \multirow[t]{2}{*}{ Total } \\
\hline & $\mathrm{F}$ & M & \\
\hline Advisor & & $11.5 \%$ & $88.5 \% 100.0 \%$ \\
\hline eminence grise & $18.8 \%$ & $81.2 \%$ & $100.0 \%$ \\
\hline executive in other firm & $8.1 \%$ & $91.9 \%$ & $100.0 \%$ \\
\hline chair of topstratum firm & & $4.7 \%$ & $95.3 \% \quad 100.0 \%$ \\
\hline lower exec. in topstratum firm & $15.7 \%$ & $84.3 \%$ & $100.0 \%$ \\
\hline pres. or CEO of topstratum firm & & $13.7 \%$ & $86.3 \% 100.0 \%$ \\
\hline signif. shareholder of topstratum firm & $2.6 \%$ & $97.4 \%$ & $100.0 \%$ \\
\hline president and chair of topstratum firm & & $2.2 \%$ & $97.8 \% \quad 100.0 \%$ \\
\hline Total & $12.3 \%$ & $87.7 \%$ & $100.0 \%$ \\
\hline
\end{tabular}

Although the entire elite of 874 networkers is unwieldy to map as a network, we can depict as its inner circle the individuals and corporations that form the 4core which we have identified as the dense centre of the carbon-capital network. Figure 6 shows both the individuals and the corporations they direct or manage. ${ }^{10}$ If the 4core provides a backbone for Calgary's oil elite, who is doing the interlocking? The 63 individuals in the 4core tend to be network specialists within the core sample - only $34.9 \%$ have any extraverted corporate affiliations. They tend to be active capitalists - only four $(6.3 \%)$ are advisers or eminence grise. And they are overwhelmingly male - only four are women. The biggest linker in the network is J.A. Brussa, a corporate lawyer who chairs Crew Energy

10. To simplify the diagram we have excluded nine companies that are linked into the 4-core by means of a single individual; thus, the sociogram displays 42 corporations and 63 individuals. A spring-embedded algorithm was used to map the points in concordance with their relative proximity to each other in the actual network (Hanneman and Riddle 2005). 
and directs eight other carbon-capital firms (all members of the 12core). Besides Brussa, R.J. Zakresky, D. Shwed, D.R. Dral, M.D Sandrelli and E. Chwyl are the key individuals who co-constitute the 12core through their multiple affiliations with its member firms. And of course, the 12 core is itself linked to other capitalist groups. In particular, Daryl H. Gilbert, Managing Director of JOG Capital and a key networker in a 6core comprised of 11 firms, sits on the board of Leucrotta Exploration, along with Brussa and Zakresky. It is through such cross-cutting affiliations that networkers like Gilbert, Zakresky and Brussa knit the corporations into a carbon-capital community.

Figure 6: The 4core as a two-mode network

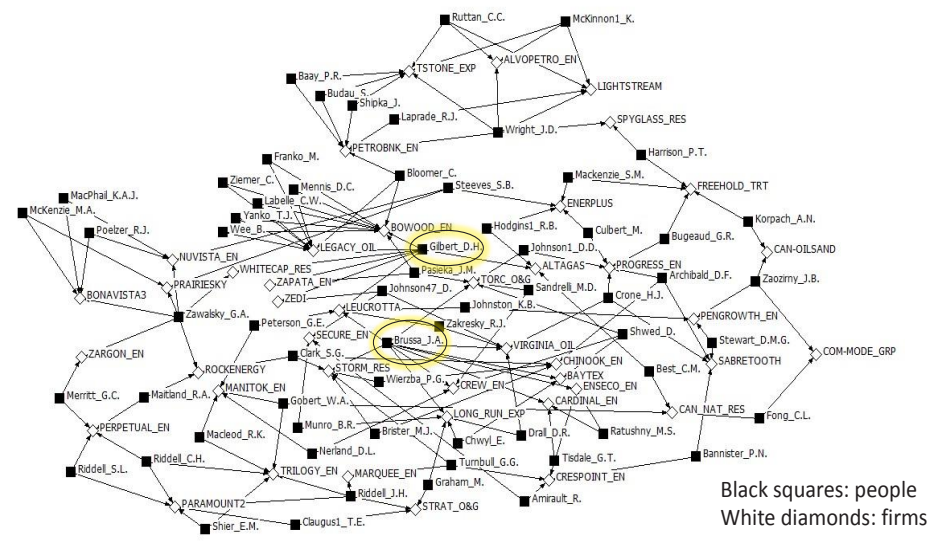

Of course, this subnetwork at the heart of the oil elite is only part of the scene. Mapping the largest connected component of carboncapital firms (Figure 7), we can see how the dense core of the network is profusely linked to the less central corporations that surround it, which include most of the carbon-capital majors. Although only Canadian Natural Resources Limited (CNRL) participates in the 4core, 11 of the 15 majors participate in the connected component, and seven are within its 3 core. 
Figure 7: The core sample's dominant component, highlighting seven majors within the 3core

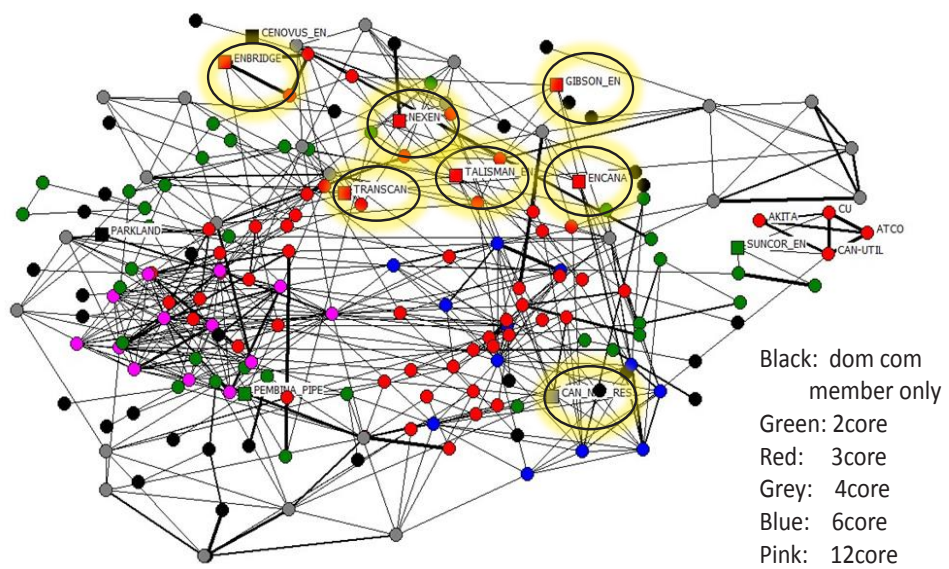

The Carbon-Capital Elite and its Neighbours

Mapping the carbon-capital subnetwork and its Canadian neighbours

How is the carbon-capital subnetwork embedded within the broader national network? In this section we consider how FF corporations are spatially positioned within the national network, and map their links to the financial sector, a key source of investment capital.

Previous research showed that the Canadian corporate network became centred in Toronto during the long postwar boom (from the late 1940 s to early 1970 s), but that in the later decades of the $20^{\text {th }}$ century Calgary and Vancouver emerged as corporate command centres, even aspiring to the status of beta-global city (Carroll 2004). Calgary is the epicentre of carbon capital, but Table 7 shows that it hosts rather few direct and indirect corporate neighbours to that sector. Instead, Canadian neighbours tend to be based in Toronto, Montreal and Vancouver. 
Table 7: Distribution of Canadian network members by city of head office

\begin{tabular}{|c|c|c|c|}
\hline City & Core sample & $\begin{array}{l}\text { Direct } \\
\text { Neighbours }\end{array}$ & $\begin{array}{l}\text { Indirect } \\
\text { Neighbours }\end{array}$ \\
\hline Vancouver & 6.3 & 15.5 & 11.5 \\
\hline Calgary & 79.4 & 13.5 & 3.3 \\
\hline Edmonton & 2.1 & 4.5 & 2.9 \\
\hline Winnipeg & 0 & 3.9 & 2.5 \\
\hline Toronto & 5.5 & 40.6 & 42.2 \\
\hline Ottawa & 0 & 0.6 & 2.9 \\
\hline Montreal & 0.4 & 12.3 & 18.4 \\
\hline Other cities & 6.3 & 8.9 & 16.3 \\
\hline & $100.0 \%$ & $100.0 \%$ & $100.0 \%$ \\
\hline
\end{tabular}

The national corporate network is structured by this geography. If we cluster its social space around Canada's major cities, as in Figure 8, the differences become clear: Calgary's highly integrated network is specialized in the FF sector (in black), with very few other industries represented. ${ }^{11}$ Vancouver hosts the second largest complement of core-sample firms, and also a variety of companies in other sectors, as direct and indirect neighbours to the carbon sector. Edmonton's network is much smaller but it resembles Vancouver's in being a centre for both core-sample firms and their neighbours. Toronto and Montreal show the obverse of Calgary's mono-sectoral profile. Montreal hosts only one core-sample company, but many neighbours. The local networks of Calgary, Vancouver, Montreal and Toronto are internally well integrated, but other cities host firms whose interlocks are extraverted toward companies based in the four main metropoli. The elite traffic among those four is extensive, and tends to converge upon Toronto. On the other hand, elite relations between corporations based in Vancouver and those based in Montreal are quite sparse.

Figure 8 also codes corporations in terms of their main economic activity, mapping the distribution of economic sectors across the landscape

11. The sociogram shows 525 corporations, based in the seven key cities, which form a connected component. It includes core-sample firms, their neighbours and neighbours of neighbours. 
of the network. I have adopted a five-fold carbon-centred categorization scheme here, which is slightly unorthodox but consistent with an analytic interest in how that sector links to others. Alongside the carbon-capital sector (black points) a carbon-related sector is distinguished, made up of industrial firms closely implicated in the FF sector, including petrochemicals, electricity, steel, transport and the automobile industry - what Urry (2013) includes within his broad conception of "carbon capital" (dark grey points). Other industries, whose connections to carbon extraction are more mediated (including non-carbon resource extraction, pharmaceuticals, food and beverage production, equipment manufacture, software, communication and media), make up a third category (in grey). The other two categories more conventionally distinguish commerce (light grey) from finance (white). I recognize that within fossil capitalism virtually all economic activities depend on carbon directly or indirectly.

Figure 8: The Canadian corporate network, clustered by seven cities, showing five economic sectors

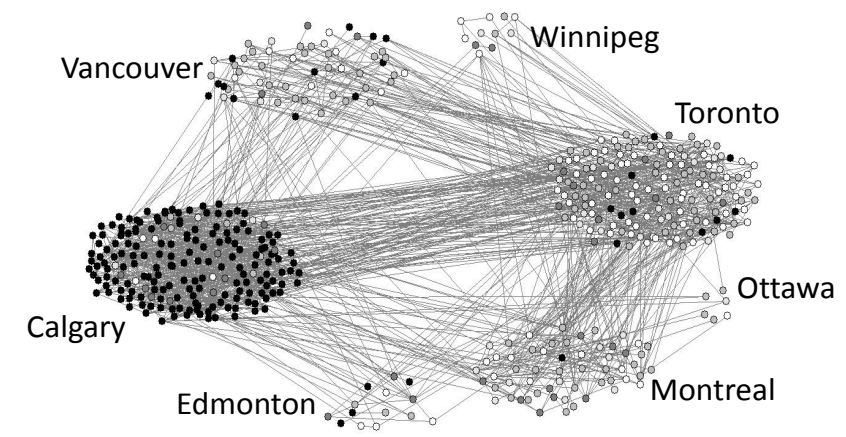

Black: carbon; Dark grey: carbon-related industrial; Grey: other industrial; Light grey: commerce; White: finance.

In the Toronto-based segment, financial capital is striking predominant, but we also see a substantial complement of more mediated production activities. Montreal's network likewise contains numerous financial institutions and a variety of industrial corporations, and to some extent this holds for Vancouver as well. Again, the mono-industrial character of Calgary's network stands out.

Symbiotic ties between industry and finance have been integral in the organization of corporate power ever since corporations emerged and grew in tandem with the modern credit system (Harvey 2006). One way of exploring this relation as it pertains to carbon capital is by analyzing the composition of the neighbourhoods of corporations, i.e., their "social circles". Considering first the $238 \mathrm{FF}$ firms, we find that 65 of them include at least one financial company in their neighbourhoods; 26 have 
two or more; ten have three or more. Interestingly, seven of those ten are majors, and the other three are not based in Calgary. Moreover, seven of the 16 firms linked to two financials are either majors (3) or based in the east (4). In other words, compared to the majors, and to core-sample firms based in other cities, the Calgary-based, mid-sized backbone of the carbon-capital network has less extensive elite ties to financial capital.

Given their enormous financing needs, it is not surprising that the majors tend to interlock with multiple financial institutions, and to participate more profusely in the national network. Nor is it surprising that carbon-sector firms based in Toronto, Montreal and Vancouver - the loci of the country's large financial institutions - tend to be more extensively interlocked with the financial sector. On the other hand, the smaller carbon-sector firms based in Calgary have more modest financing needs and more local orientations, in a city that lacks large financial institutions.

Looked at from the other side, among the 126 Canadian financial, investment and real estate corporations in our sample, 45 are tied to at least one FF company; 21 have two or more such interlocks; 12 have three or more. Thirteen of the 21 with links to multiple carbon-capital firms are based in Toronto; one is based in Calgary.

If we focus on the seam between these two key sectors, and the firms whose boards interlock extensively with each other, across that seam, we arrive at the connected component in Figure 9, which consists of 36 firms: $20 \mathrm{FF}$ companies (in blue) and 16 financials (in pink). ${ }^{12}$ Here we see an intermingling of carbon capital predominantly based in Calgary (blue circles) and financial capital predominantly based in Toronto (pink diamonds). Ten of the $15 \mathrm{FF}$ majors participate; Imperial Oil, Teck Resources, CNRL, Enbridge and TransCanada interlock with multiple financials - clarifying that their ties to major eastern-based financial corporations are a key aspect of the mediating role they play between Calgary's corporate community and the broader national formation. Along this seam between carbon capital and finance, the most central financial institutions are the Royal Bank of Canada, Toronto-Dominion Bank, Sun Life, Manulife, Brookfield Asset Management and Great-West Life. Such profuse ties are to be expected, in view of the extensive financing needs of the majors as they pursue megaprojects requiring massive fixed-capital investment. The elite ties reflect a deeply structured symbiosis between industry and finance (Harvey 2006).

12. The sociogram excludes isolates from the connected component: six FF companies interlocked with multiple financials and five financials interlocked with multiple FF companies. 
Figure 9: Key interlocks between Canadian carbon and financial sectors

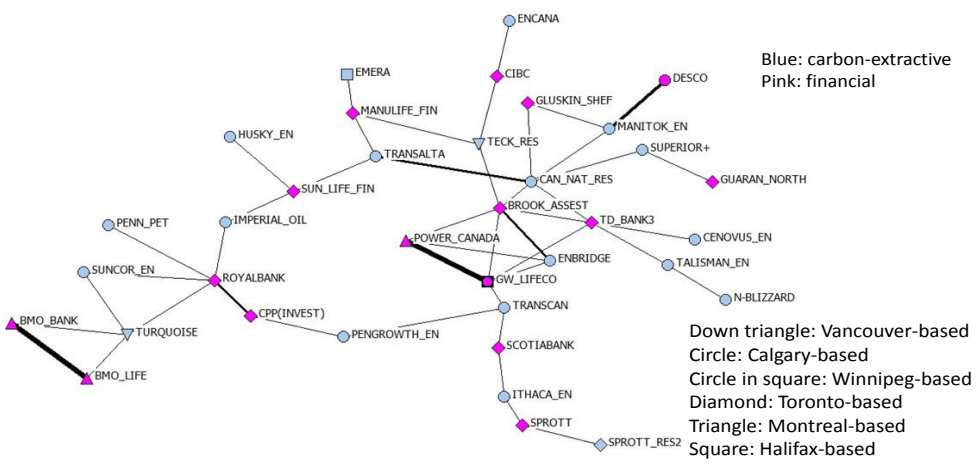

\section{Linking into the transnational corporate network}

Earlier we observed how corporate concentration shapes the carbon-capital community, as the largest companies mediate between the local and the extra-local. This mediating role also appears in the composition of social circles around the 15 majors. In Figure 10, the social circles interpenetrate extensively, forming a connected network of the 15 majors and 174 neighbours. Most of the majors (and particularly CNRL, Enbridge, Encana, TransCanada and Nexen) link extensively to both the core network (in red) and the network of Canadian and foreign neighbours (in pink and green, respectively). Husky Energy (located in the south-east of the sociogram) is a noteworthy exception. Its neighbourhood reaches into the Canadian corporate network via a single interlock with Sun Life Financial. Otherwise, Husky is embedded in a foreign corporate group organized around its Hong Kong-based controlling shareholder, Hutchison Holdings (and the family of mega-billionaire Li Ka-shing, who owns Hutchison).

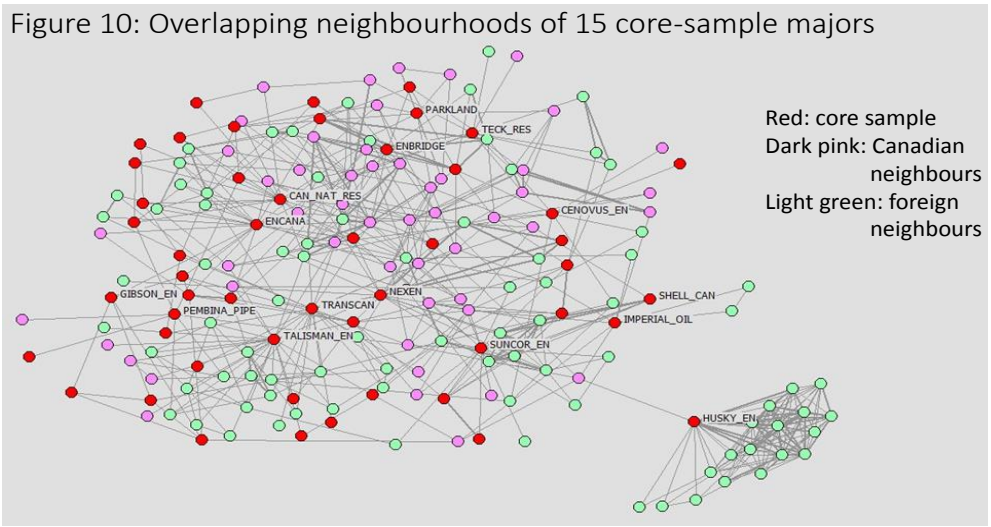


Again, we find the majors (in particular, those controlled by Canadian capitalists) playing a mediating role between the local scene and the extralocal formations of corporate power - distinct from the mid-sized FF companies that interlock with each other as a local corporate community. The demography of the FF sector weights the core network in a localist direction: most of the active carbon-sector capitalists are centred in Calgary and connected into a highly cohesive, somewhat introverted local network. But the largest concentrations of capital, and of corporate power, pull the network toward national and transnational scale.

However, transnationality is not simply a matter of scale. As argued elsewhere (Carroll 2010), the transnational corporate network is itself highly regionalized: most interlocking occurs in the same region, and the global network is organized around a North-Atlantic core, as in Van der Pijl's (1984) conception of an "Atlantic ruling class". When we consider the domicile of the foreign corporate neighbours to Canada's carbon-capital elite, we find that $58.8 \%$ of direct foreign neighbours are based in North America (including the US plus the three tax havens of Bermuda, Cayman Islands and Curacao), 23.1\% are based in the affluent "core" of Europe and 9.2\% are based in the Asia-Pacific core of Japan, South Korea, Hong Kong, Australia and New Zealand. That is, most of the foreign corporations whose directors and executives interlock with Canada's carbon-capital community are based in the US and the other core zones of the world economy. The same holds for foreign firms indirectly linked to Canada's carbon-capital community: $61.4 \%$ are based in the rest of North America, $22.0 \%$ are based in the core states of Europe and 9.4\% are based in the core Asia-Pacific region. Thus, foreign neighbours are based in the US, followed by the world economy's other two core zones - Europe and the Asia-Pacific. Of the 31 direct and indirect neighbours based on the Asian semi-periphery, 22 are headquartered in mainland China, six in India and three in Malaysia. Overwhelmingly, Canada's carbon-capital elite is nested within the classic Triad of North America, Western Europe and Japan/Australia, reflecting the well-established contours of the transnational capitalist class (Carroll 2010; Burris and Staples 2012).

The actual elite relations among Canadian carbon-capital firms and the national and transnational corporate network are strongly shaped by this pattern of participation. Our snowball sampling identifies the complete network of interlocks among Canada's carbon-capital sector and all immediate neighbours. Row/column percentages in Table 8 break down the total volume of directorate interlocking in that transnational network, by each region of the world system. We see that firms based in Canada link predominantly to other Canada-based firms - whether core-sample or neighbours. Interlocks among core-sample firms and their Canadian neighbours make up $56.11 \%$ of interlocks in the entire network, which is 
strongly clustered on a regional basis (only $18.96 \%$ of all interlocks link across the region/country categories in the table). The Canadian network is highly introverted - strongly integrated but more sparsely linked to the transnational network in which it is embedded. Indeed, its E-I score $(-0.600)$ shows the Canadian network to be far more introverted than the carbon-capital subnetwork it contains. This indicates the continuing cohesiveness of Canada's corporate community. It also points to that community's focal role vis-à-vis the carbon-capital elite nested within it. Beyond domestic interlocks, Canada's carbon-capital sector links primarily to the core regions of the North Atlantic; indeed, $93.17 \%$ of the total volume of interlocking in the transnational network connects corporations based in the North Atlantic. Outside that zone, nearly all interlocks involve firms based in the core (5.14\%) and semi-peripheral (1.59\%) zones of South and East Asia. The transnational elite connections of Canadian carbon capital do not as a rule extend to the Middle East, Eastern Europe, Latin America and Africa.

Table 8: Percentage Distribution of interlocks by company domicile in the world system

\begin{tabular}{|c|c|c|c|c|c|c|c|c|c|c|}
\hline $\begin{array}{l}\text { Region/ } \\
\text { country }\end{array}$ & $\begin{array}{l}\text { Canada: } \\
\text { core } \\
\text { sample }\end{array}$ & $\begin{array}{l}\text { Canada: } \\
\text { neighbours }\end{array}$ & $\begin{array}{l}\text { Rest of } \\
\text { North } \\
\text { America* }\end{array}$ & $\begin{array}{l}\text { Core } \\
{ }^{*} \text { Europe }\end{array}$ & $\begin{array}{l}\text { Core } \\
\text { Asia- } \\
\text { Pacific }\end{array}$ & $\begin{array}{l}\text { S-P } \\
\text { Latin } \\
\text { America }\end{array}$ & $\begin{array}{l}\text { S-P East } \\
\text { Europe/ } \\
\text { Middle } \\
\text { East }\end{array}$ & S-P Asia & Africa & Total \\
\hline $\begin{array}{l}\text { Canada: } \\
\text { core sample }\end{array}$ & 32.48 & 8.58 & 5.62 & 2.49 & 0.89 & 0.03 & 0.17 & 0.51 & 0.03 & 50.8 \\
\hline $\begin{array}{l}\text { Canada: } \\
\text { neighbours }\end{array}$ & 8.58 & 15.05 & 3 & 1.19 & 0.1 & 0 & 0 & 0 & 0 & 27.92 \\
\hline $\begin{array}{l}\text { Rest of } \\
\text { North } \\
\text { America* }\end{array}$ & 5.62 & 3 & 18.93 & 2.08 & 0.85 & 0 & 0 & 0 & 0 & 30.48 \\
\hline Core Europe & 2.49 & 1.19 & 2.08 & 3.75 & 1.43 & 0 & 0.1 & 0.1 & 0 & 11.14 \\
\hline $\begin{array}{l}\text { Core Asia- } \\
\text { Pacific }\end{array}$ & 0.89 & 0.1 & 0.85 & 1.43 & 1.5 & 0 & 0 & 0.37 & 0 & 5.14 \\
\hline $\begin{array}{l}\text { S-P Latin } \\
\text { America }\end{array}$ & 0.03 & 0 & 0 & 0 & 0 & 0.07 & 0 & 0 & 0 & 0.1 \\
\hline $\begin{array}{l}\text { S-P East } \\
\text { Europe/ } \\
\text { Middle East }\end{array}$ & 0.17 & 0 & 0 & 0.1 & 0 & 0 & 0.07 & 0 & 0 & 0.34 \\
\hline S-P Asia & 0.51 & 0 & 0 & 0.1 & 0.37 & 0 & 0 & 0.61 & 0 & 1.59 \\
\hline Africa & 0.03 & 0 & 0 & 0 & 0 & 0 & 0 & 0 & 0 & 0.03 \\
\hline Total & 50.8 & 27.92 & 30.48 & 11.14 & 5.14 & 0.1 & 0.34 & 1.59 & 0.03 & [100] \\
\hline
\end{tabular}

*US, Bermuda, Cayman Islands and Curacao. S-P: Semi-Peripheral countries Note: figures do not add to $100 \%$ since off-diagonal entries appear twice 
In Figure 11 a full view of the entire transnational network conveys another sense of the mediating role that the majors play, in this case between foreign and Canadian corporations. Nearly all Top Strata corporations we identified through snowball sampling form a connected component of 1162 firms. In this sociogram, nodes are colour-coded according to sample stratum: red for the core sample, pink for direct neighbours based in Canada, light pink for indirect neighbours based in Canada, light green for foreign-based direct neighbours and dark green for foreign-based indirect neighbours. As with the other sociograms in this article (with the exception of Figure 8), nodes are positioned in concordance with their relative proximity to each other in the actual network (see note 10). The network's topography has of course been strongly conditioned by the snowball sampling: indirect neighbours connect with core sample members only at one remove; thus core-sample firms are tend to be at one end of the network, with indirect neighbours at the other.

Figure 11: Core sample as embedded in the entire transnational network

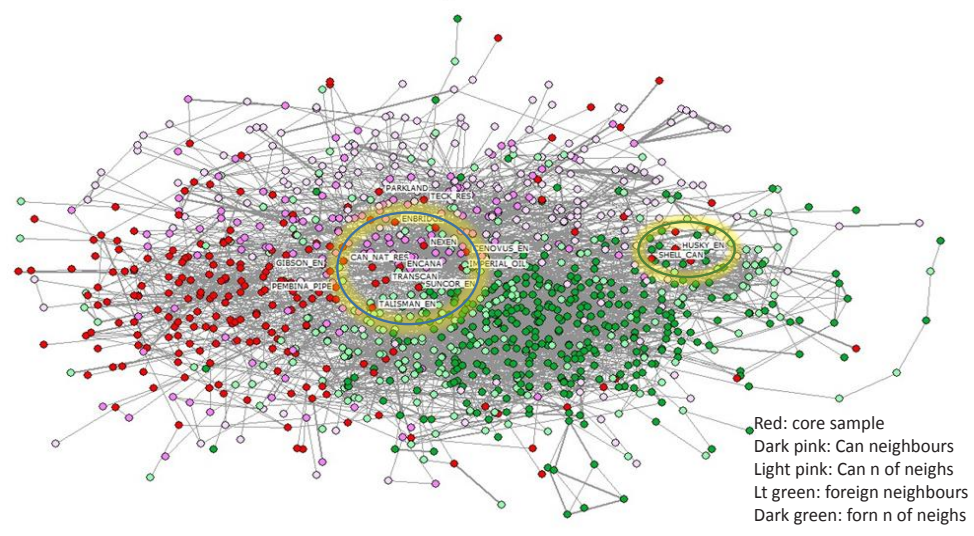

Where do the 15 Canadian carbon-capital majors fit into this space? With a few partial exceptions (four of the smaller majors - Gibson Energy and Pembina Pipeline, Parkland Fuel and Teck Corporation) they are positioned more on the side of the neighbouring strata, both Canadian and foreign. Suncor, Talisman, Imperial Oil and Cenovus occupy a liminal zone between the predominantly Canadian network to the left and the predominantly foreignbased network to the right. In contrast, Husky and Shell, both controlled by foreign owners, are ensconced in the transnational network. The majors are either distant from the carbon-capital network (Shell and Husky), or they tend to mediate between it and the wider world of transnational capital. 


\section{Discussion}

This article began with the problem of concentrated corporate power, focusing on the strategically key carbon-extractive sector. What does a network analysis of the carbon-capital elite reveal about this problem and the obstacles it might pose to a just transition from fossil capitalism?

Regarding the carbon-capital elite's accumulation base, pronounced economic concentration shapes the landscape of corporate power, lodging it in four major urban centres: pre-eminently (for carbon capital) Calgary, then Toronto, Vancouver and Montreal. The majors dominate particularly in the capital-intensive sectors: integrated oil and gas production and pipelines. While majors claim the lion's share of the sector's revenue, most carboncapital firms are mid-sized, and although western Canada is the primary production site many companies are invested in other locales, national and international. Most firms - whether majors or mid-sized - are controlled by interests based in Canada, and this tendency has strengthened recently as global majors such as Shell and ConocoPhillips have sold their tar sands assets to Canadian majors (Pineault and Hussey 2017).

Economic concentration is amplified by the social organization of corporate power. A relatively few directors and executives are corporate networkers, and a small proportion of them accounts for most interlocking, both among carbon-capital firms and in the wider network of their neighbours. Most corporate interlocking among carbon-extractive firms occurs within a single city and among one-fifth of the companies. But despite the high level of cohesion among the boards of Calgary-based companies, the carbon-capital elite is not an entity onto itself; it is a fraction nested within the national corporate elite, with additional ties to the transnational network. The individuals who comprise the elite (and even more, its inner circle) are overwhelmingly male and engaged in top-level management - not simply corporate window dressing. Corporate power's spatial organization concentrates command over carbon resources largely in Calgary, while financial and other corporations are based in Toronto and to a lesser extent Montreal and Vancouver. Directorate interlocks stitch corporations into a national elite network. In its transnational connections (where the carbon majors are especially active), the network is concentrated largely within the North Atlantic zone of the global economy, the heartland for a transnational capitalist class.

The majors, several of which are controlled by foreign interests, link into the local network but are not at its centre. Instead, they play a multifaceted mediating role:

- $\quad$ between the highly cohesive, somewhat introverted Calgary-based network and corporations based elsewhere; 
- more specifically, between eastern-based financial capital (with which the majors have profuse ties) and western-based carbon capital;

- between the Canadian corporate community and the wider world of transnational capital.

The top tier of Canada's carbon-extractive sector, while relatively marginal to the Calgary-centred network, integrates the carbon-capital elite with other segments of corporate power, both nationally and transnationally. But ancillary organizations also provide such integrative capacity. For instance, the sharply stratified character of the carbon-extractive sector is recognized by its primary representative body, the Canadian Association of Petroleum Producers. Its board of governors is "balanced," with 10 governors selected from the 15 largest member firms, 10 from the next 30 members and 10 from smaller companies (CAPP website http://www.capp.ca/about-us/ourorganization; access date: June 15, 2017). In presenting a single voice for the oil and gas sector, CAPP also mediates possible fractional divisions between big and mid-sized capital.

These mediating relations are important, both economically and politically. Although the local Calgary network is highly integrated, it is also highly specialized: the carbon-capital elite is spatially concentrated, setting up a symbiosis with sources of finance located elsewhere, but also the potential for political conflict between regionally inflected carbon-capital interests and other fractions within Canadian capitalism, such as eastern-based manufacturing - a dynamic evident since the National Energy Program of the early 1980s (Laxer 2015:46-9). The sector over which the carbon-capital elite presides has been an enormously profitable motor of regional accumulation, with spread effects via commodity chains and fiscal/financial skim-off. Yet sharpening ecological concerns, both global and site-specific (as in local risks of carbon transport by land and water) portend intensified regional conflict over energy futures.

\section{CONCLusion}

The architecture of corporate power in and around the carbon-capital sector is integrated, to the point of appearing as an entrenched oligarchy. Its oligarchic form represents a key aspect of what is sometimes called "business as usual". In corporate boardrooms, decisions affecting communities, workers and ecologies are made by small, often interlocked groups of men, according to a criterion that privileges short-term private profit over public and ecological concerns. At least since Britain's 2006 Stern Review (Stern 2006) "business as usual" has also referred to a climate scenario in which the current regime of largely unregulated corporate power is simply extended into 
the future. In the Stern Review and elsewhere, the projection is ecological and economic decline, in the current century, as catastrophic climate change erodes the basis for living systems, and thus for economic life.

Clearly, the concentration and oligarchic organization of corporate power within an energy sector increasingly seen as ecologically problematic requires a robust response, to which both policy sociology and public sociology can contribute. Regarding policy, public regulation of carbon capital must be an important part of the response, particularly in the short term. Higher royalties on carbon extracted, and taxes on carbon usage, can raise funds for climate change mitigation and for facilitating a transition to energy alternatives, including the creation of "climate jobs". ${ }^{13}$ Tighter controls on emissions and thus on existing and proposed carbon-extractive projects, including full-cost accounting and polluter-pay provisions that prevent corporations from externalizing extraction's environmental costs, are also obvious regulatory practices that should be adopted. Although provincial governments, beginning with BC's in 2008, have gestured toward such regulation, the chasm between aspiration (i.e., the 1.5 degree Celsius global temperature endorsed by Canada and other countries at the 2015 COP meeting at Paris) and reality is daunting. In 2015, Alberta paid a steep price in securing support of corporate majors for its climate plan, which allows tar sands emissions to increase by 43 percent by 2020 while protecting every plant in operation now, and green-lighting ones currently under construction (Washburn 2015).

Still, serious regulatory measures that redirect revenues to public purposes while blocking the most ecologically damaging corporate initiatives should not be discounted. Regulation, however does not touch the actual basis of corporate power - the concentrated ownership of capital and the control of capital through corporate forms of organization. The scientific consensus holds that, to avoid catastrophic climate change, the world will have to decarbonize energy in the next three decades. As an integral aspect of this most of the world's carbon (and especially the dirtiest deposits) must remain in the ground. "Business as usual", in particular, the quest by big carbon to valorize massive fixed-capital investments, conflicts with the requirement to decarbonize energy in a rapid and socially just manner. Backed by an equally oligarchic financial sector and by generous state subsidies, carbon-capital corporations have sunk enormous investments into tar sands and other megaprojects. The same corporations continue to push for expansion of pipeline infrastructure that will either lock Canada's energy sector

13. See for instance the Green Economy Network's 2015 proposal to create one million climate jobs in Canada through federal spending on renewable energy, energy efficiency, and public transportation, over five years. http:// greeneconomynet.cfswpnetwork.ca/one-million-climate-jobs-challenge/ (access date: June 15, 2017). 
into more "business as usual", or result in vast stranded assets and writedowns, if oil prices fail to recover to pre-autumn 2014 levels. Corporate control of the financing and production of energy poses the greatest obstacle to our dealing effectively with the ecological and economic challenges we face today.

Robust regulatory practices therefore need to be complemented by measures that actually shift power, in both senses of the term: from fossil-fueled power to renewables (decarbonization) and from corporate oligarchy to public, democratic control of economic decisions (democratization). The combination of decarbonization and economic democratization, termed energy democracy, has been endorsed by the international trade union movement, including Canada's largest unions and the Canadian Labour Congress, through Trade Unions for Energy Democracy. ${ }^{14}$ Energy democracy offers an appealing alternative to the carbon-capital oligarchy whose network we have mapped here. Laxer's (2015:230) proposal for a Canadian "ecological security plan" points Canadians toward the goal of energy democracy. His plan combines strong regulatory measures with a shift away from private, for-profit ownership and control, as energy companies are converted to or displaced by public-interest, not-for-profit entities. As Laxer (2015:231-3) acknowledges, carbon capital and aligned interests in media and other sectors will stridently oppose efforts to shift power and to democratize energy.

Our findings suggest further the need to extend economic democratization beyond carbon capital per se. Energy corporations are a central component of a wider power structure, "with the financial industry intricately linked to the financing, insurance and speculative interests of the oil and gas sector" (Albo and Yap 2016). Divestment from fossil fuels and redirection to energy alternatives constitute the most immediate response to this challenge, but given the symbiosis between carbon capital and the financial sector, evident in the elite ties mapped here, a robust energy democracy will need to bring the financial sector itself under democratic control.

Democratizing energy and finance are aspirations not easily achieved, but there is an urgent need to begin a public discussion that can lead to action, if decarbonization is to be sufficiently rapid and just. This is where public-sociology initiatives can bear fruit, as in the University of Victoriahosted Corporate Mapping Project ${ }^{15}$ and the University of Alberta's Petrocultures Research Cluster. ${ }^{16}$

14. See http://unionsforenergydemocracy.org/ (access date: June 15, 2017). Formed in the wake of a roundtable of trade unionists in 2012, TUED currently includes 47 unions in 17 countries.

15.http://www.corporatemapping.ca/ (access date: June 15, 2017).

16. http://petrocultures.com/ (access date: June 15, 2017). 


\section{REFERENCES}

Adkin, Laurie E. 2016. Ecology and governance in a First World petro-state. pp. 3-50 in Laurie E. Adkin (ed.), First World Petro-Politics: The Political Ecology and Governance of Alberta. Toronto: University of Toronto Press.

Albo, Greg and Lilian Yap. 2016. From the Tar Sands to "Green Jobs"? Work and ecological justice. The Bullet 1280 (12 July) https://socialistproject. ca/bullet/1280.php (access date: June 15, 2017).

Altvater, Elmer. 2006. The social and natural environment of fossil capitalism. In Socialist Register 2007, edited by Leo Panitch and Colin Leys, 36-59. Halifax: Fernwood Publishing.

Brandeis, Louis D. 1914. Other People's Money. Louis D. Brandeis School of Law Library http://louisville.edu/law/library/special-collections/thelouis-d.-brandeis-collection/other-peoples-money-by-louis-d.-brandeis (access date: June 15, 2017).

Brennan, Jordan. 2012. A shrinking universe: How concentrated corporate power is shaping income inequality in Canada. Ottawa: Canadian Centre for Policy Alternatives https://www.policyalternatives.ca/publications/ reports/shrinking-universe (access date: June 15, 2017).

Burris, Val and Clifford L. Staples. 2012. In search of a transnational capitalist class: Alternative methods for comparing director interlocks within and between nations and regions. International Journal of Comparative Sociology 53(4):323-342.

Carroll, William K. 1984. The individual, class, and corporate power in Canada. Canadian Journal of Sociology 9:245-68.

Carroll, William K. 1986. Corporate Power and Canadian Capitalism. Vancouver: University of British Columbia Press.

Carroll, William K. 2004. Corporate Power in a Globalizing World. Toronto: Oxford University Press

Carroll, William K. 2010. The Making of a Transnational Capitalist Class. London: Zed Books

Carroll, William K and Jerome Klassen. 2010. Hollowing out Corporate Canada? Changes in the corporate network since the 1990s. Canadian Journal of Sociology 35(1):1-30.

Carter, Angela V. 2014. Petro-capitalism and the Tar Sands. In A Line in the Tar Sands, edited by Toban Black, Tony Weis, Stephen D'Arcy and Joshua Kahn Russell, 23-35. Toronto: Between the Lines.

Clarke, Tony, Diana Gibson, Brendan Haley and Jim Stanford. 2013. The Bitumen Cliff. Ottawa: Canadian Centre for Policy Alternatives https://www. policyalternatives.ca/publications/reports/bitumen-cliff (access date: June 15, 2017) 
Domhoff, G. William. 2006. Who Rules America? New York: McGraw-Hill.

Fennema, Meindert and Eelke M. Heemskerk. 2017. When theory meets methods: The naissance of computer assisted corporate interlock research. Available at SSRN: https://ssrn.com/abstract=2827627 (access date: June $15,2017)$.

Hanneman, Robert A. and Mark Riddle. 2005. Introduction to Social Network Methods. Riverside, CA: University of California, Riverside http://faculty.ucr.edu/ hanneman/nettext/C4 netdraw.html\#location (access date: June 15, 2017).

Harvey, David. 2006. The Limits to Capital. London: Verso.

Helland, Eric and Michael Sykuta. 2004. Regulation and the evolution of corporate boards: monitoring, advising, or window dressing? Journal of Law and Economics 47(1):167-193.

Klassen, Jerome and William K. Carroll. 2014. Transnational Class Formation. Globalization and the Canadian Corporate Network. In Jerome Klassen, Joining Empire, 154-79. Toronto: University of Toronto Press.

Krackhardt, David and Robert N. Stern. 1988. Informal networks and organizational crisis: an experimental simulation. Social Psychology Quarterly 51(2):123-40.

Laxer, Gordon. 2015. After the Sands: Energy and Ecological Security for Canadians. Madeira Park, BC: Douglas and McIntyre.

Leggett, Jeremy. 2005. Half Gone. London: Portobello Books.

McCormack, Geoffrey and Thom Workman. 2015. The Servant State. Halifax: Fernwood.

Macdonald, David. 2014. Outrageous Fortune: Documenting Canada's Wealth Gap. Ottawa: Canadian Centre for Policy Alternatives, 3 April https:// www.policyalternatives.ca/outrageous-fortune

Macdonald, David. 2015. The Wealth Advantage: The Growing Wealth Gap Between Canada's Affluent and the Middle Class. Canadian Centre for Policy Alternatives, 25 June https://www.policyalternatives.ca/wealthadvantage (access date: June 15, 2017).

Malm, Andreas. 2016. Fossil Capital. New York: Verso.

Mills, C. Wright. 1956. The Power Elite. New York: Oxford University Press.

Pineault, Éric. 2016. Welcome to the age of extractivism and extreme oil. $\mathrm{Na}$ tional Observer, May 18 (access date: June 15, 2017).

Pineault, Éric and Ian Hussey. 2017. Restructuring in Alberta's oil industry: Internationals pull out, domestic majors double down. Corporate Mapping Project, April 18 http://www.corporatemapping.ca/restructuringin-albertas-oil-industry-internationals-pull-out-domestic-majors-doubledown/ (access date: June 16, 2017). 
Piedalue, Gilles. 1976. Les groups financiers au Canada 1900-1930. Revue d'Histoire de l'Amerique Française 30 (1):3-34.

Porter, John. 1956. Concentration of economic power and the economic elite in Canada. Canadian Journal of Economics and Political Science 22:199220.

Porter, John. 1965. The Vertical Mosaic. Toronto: University of Toronto Press.

Sapinski, J.P. and William K. Carroll. 2017. Interlocking directorates and corporate networks.In Handbook of the International Political Economy of the Corporation, edited by Andreas Nölke and Christian May. Cheltenham Glos, UK: Edward Elgar Publishing Ltd.

Seidman, S. 1983. Network structure and minimum degree. Social Networks 5:269-87.

Stendie, Larissa and Laurie E. Adkin. 2016. In the path of the pipeline: Environmental citizenship, Aboriginal rights, and the Northern Gateway Pipeline Review. In First World Petro-Politics: The Political Ecology and Governance of Alberta, edited by Laurie E. Adkin, 417-55. Toronto: University of Toronto Press.

Stern, Nicholas. 2006. Stern Review: Report on the Economics of Climate Change. London: Her Majesty's Treasury. http://webarchive.nationalarchives.gov.uk/+/http:/www.hm-treasury.gov.uk/independent_reviews/ stern_review_economics_climate_change/stern_review_report.cfm (access date: June 15, 2017).

Urry, John. 2013. Societies Beyond Oil. London: Zed Books.

Useem, Michael. 1984. The Inner Circle. New York: Oxford University Press.

Van der Pijl, Kees. 1984. The Making of an Atlantic Ruling Class. London: Verso.

Vitali, Stefania, James B. Glattfelder and Stefano Battison. 2011. The network of global corporate control. PLoS ONE 6(10), e25995 arXiv:1107.5728v2 [q-fin.GN] (access date: June 15, 2017).

Washbrook, Kevin. 2015. Why are people cheering Alberta's climate plan? The Tyee 16 December http://thetyee.ca/Opinion/2015/12/16/Cheering-Alberta-Climate-Plan/ (access date: June 15, 2017).

\section{ACKnowledgements}

This paper is part of the Corporate Mapping Project (CMP), a research and public engagement initiative investigating the power of the fossil fuel industry. The CMP is jointly led by the University of Victoria, Canadian Centre for Policy Alternatives and the Parkland Institute. The CMP is funded primarily by the Social Science and Humanities Research Council (SSHRC). 
William K. Carroll is a professor in the Sociology Department at the University of Victoria. His most recent books, published in 2016, are Expose, Oppose, Propose: Cognitive Praxis in the Struggle for Global Justice and A World to Win: Counter-Hegemony and Contemporary Social Movements (with Kanchan Sarker). His current project, "Mapping the power of the carbon-extractive corporate resource sector" (co-directed with Shannon Daub of CCPA-BC), traces modalities of corporate power within the global political economy, focusing on fossil capitalism in western Canada.

Email: wcarroll@uvic.ca 